Agata Orzechowska, Monika Talarowska, Krzysztof Zboralski*

\title{
WYBRANE TRUDNOŚCI I DYLEMATY ETYCZNE W ZAKRESIE PSYCHOLOGICZNYCH ASPEKTÓW PROWADZENIA BADAŃ NAUKOWYCH I KLINICZNYCH
}

\section{WPROWADZENIE}

Relacja między osobą badaną a diagnostą ma zawsze charakter niesymetryczny. Nierówność oznacza tu wyrażanie zgody uczestników tego typu kontaktu na to, że jeden z nich ma wyższe kompetencje niż drugi. W centrum zainteresowania znajduje się osoba badana, co oznacza, że wszystkie osobiste potrzeby, przekonania i zmartwienia diagnosty powinny być pomijane. Relacja ta jest związkiem formalnym, w której realizowana jest usługa profesjonalna i wypełniana jest specyficzna rola społeczna, której treścią może być niesienie pomocy lub rozwój nauki, a którą to usługę i relację osoby badane rozumieją i akceptują.

Istota różnicy między badaniem dla celów naukowych a diagnozowaniem w celach klinicznych nie leży w odmienności stosowanej procedury, ale w preferowanych celach oraz rodzaju zmiennych, które uznaje się za istotne. Przyjmuje się, że badanie diagnostyczne jest w swej istocie badaniem naukowym, a postępowanie naukowców powinno być dla diagnostów wzorcem. Jednak psycholog w roli badacza ma inne cele niż w roli diagnosty, a rodzaj zmiennych, które uznaje za ważne dla danego zjawiska różnią się (P a l u c h o w s k i 2007).

Spory i kontrowersje wokół prowadzenia badań w celach diagnostycznych (klinicznych) i w celach naukowych często są źródłem nieporozumień, konfliktów i dylematów etycznych dotyczących postępowania podczas realizacji tych procedur.

* Psychologowie kliniczni, doktorzy nauk medycznych, specjaliści, pracownicy naukowi, Klinika Psychiatrii Dorosłych, Uniwersytet Medyczny w Łodzi, ul. Aleksandrowska 159, 91-229 Łódź; agata.orzechowska@umed.lodz.pl, monika.talarowska@umed.lodz.pl, krzysztof.zboralski@umed. lodz.pl.

Każdy z trzech autorów wniósł równorzędny wkład w powstanie niniejszego tekstu. 


\section{ROLA PSYCHOLOGA W BADANIACH NAUKOWYCH I KLINICZNYCH}

Tradycyjnie rozróżniamy dwie główne dziedziny psychologii: psychologię teoretyczną, której domeną jest poszukiwanie ogólnych prawidłowości kierujących różnymi formami aktywności człowieka i psychologię stosowaną, zajmującą się praktycznym zastosowaniem tych prawidłowości w różnych sferach życia i działalności człowieka. Poszczególne działy psychologii stosowanej wyodrębnia się przez wskazanie terenu praktycznego wykorzystania teorii psychologicznej. Psychologię na terenie medycyny przez szereg lat wiązano niemal wyłącznie z psychiatrią. Dominującą rolę odgrywała tutaj psychologia kliniczna, którą utożsamiano z psychologią zaburzeń psychicznych. Uważa się, że psychopatologia jest podstawową dziedziną zarówno dla psychiatrii, jak i dla psychologii klinicznej.

Przez długi czas obszar zainteresowania psychologii klinicznej dotyczył głównie zaburzeń psychicznych, zaburzeń zachowania i ich psychospołecznych przyczyn oraz zaburzeń somatycznych uwarunkowanych czynnikami psychospołecznymi, a także wpływu zaburzeń somatycznych na funkcjonowanie psychiczne. Obecnie psychologowie kliniczni coraz częściej zainteresowani są również zdrowiem psychicznym i zdrowiem rozumianym całościowo jako pełny biopsychospołeczny dobrostan. Współczesna psychologia kliniczna jest jedną z najważniejszych dziedzin psychologii stosowanej i zajmuje się zarówno zdrowiem, jak i różnymi postaciami zaburzeń uwzględniając wszystkie fazy życia człowieka oraz obejmując różne grupy społeczne. Jej przedmiot można określić jako zespół twierdzeń opisujących zaburzenia zachowania i funkcji somatycznych, wyjaśniających biopsychospołeczny mechanizm tych zaburzeń, określających przyczyny i uwarunkowania zaburzeń i zdrowia oraz sposoby postępowania w celu ochrony zdrowia, zapobiegania i terapii zaburzeń ( $\mathrm{C} \mathrm{z}$ a b a ła, S ę k 2005; S ę k 2005).

Psychologia jako profesja i jako dyscyplina naukowa należy do tych dziedzin ludzkiej aktywności, w których centrum zainteresowania i oddziaływań jest człowiek. Relacje interpersonalne nawiązywane przez psychologa występującego zarówno w roli praktyka, jak i badacza lub nauczyciela, podobnie jak wszelkie relacje międzyludzkie, posiadają zawsze wymiar etyczny. Relacje te mają jednak szczególny, niesymetryczny charakter wynikający z przewagi kompetencji interpersonalnych po stronie psychologa, który dysponuje specjalistyczną wiedzą i technikami służącymi do poznawania innych ludzi i oddziaływania na nich.

Rola zawodowa psychologa obejmuje ingerencję w sposób istnienia drugiego człowieka jako indywidualnej i niepowtarzalnej całości, ingerencję, której skutki mogą być nieodwracalne. Te okoliczności decydują o znaczeniu przestrzegania zasad etyki zawodowej w działalności psychologów i uzasadniają stawianie im wysokich wymagań etycznych. Naczelną wartością dla psychologa jest dobro drugiego człowieka, a celem jego działalności profesjonalnej jest niesienie pomo- 
cy innej osobie w rozwiązywaniu trudności życiowych i osiąganiu lepszej jakości życia na drodze rozwoju indywidualnych możliwości oraz ulepszaniu kontaktów międzyludzkich. W badaniach cel ten istnieje w dalszej perspektywie. Kontakt nawiązywany w celach badawczych, jeśli w swoich założeniach nie ma być pomocny, to przynajmniej nie powinien przynieść uszczerbku osobom uczestniczącym w badaniach (Kodeks Etyczno-Zawodowy Psychologa... 1991 - dalej jako KEZ).

Mimo różnych porządków moralnych i światopoglądowych istnieje zespół podstawowych wartości humanistycznych, które znalazły wyraz w Powszechnej Deklaracji Praw Człowieka ONZ. W swoich czynnościach zawodowych psycholog zawsze powinien respektować te podstawowe wartości, zwłaszcza godność osoby ludzkiej, podmiotowość i autonomię człowieka i jego prawo nieskrępowanego rozwoju. Psycholog uznaje prawo każdego człowieka do kierowania się własnym systemem wartości, dokonywania własnych wyborów, jak również prawo do intymności. Jednocześnie psycholog świadomy jest skutków, jakie przynosi lub przynieść może w przyszłości jego oddziaływanie - ostatecznie powinny to być skutki pomyślne dla odbiorcy lub odbiorców czynności zawodowych psychologa. W każdym przypadku na psychologu ciąży odpowiedzialność za następstwa kontaktu, jaki w ramach swojej roli zawodowej nawiązuje z drugim człowiekiem. Granice ingerencji psychologa wyznaczone są z jednej strony jego kompetencjami profesjonalnymi, z drugiej - celami i oczekiwaniami formułowanymi przez osoby zgłaszające się po pomoc psychologiczną.

Współpracując z przedstawicielami innych zawodów, psycholog nie przekracza granic swoich kompetencji i szanuje kompetencje innych specjalistów. Jednocześnie dba o utrzymanie własnej tożsamości zawodowej, respektuje cele i wartości właściwe własnej profesji i wystrzega się identyfikacji z postawami innych specjalistów, jeśli te postawy są niezgodne z zasadami etycznymi zawodu psychologa. Zasada ta obowiązuje zawsze, ilekroć psycholog występuje w swojej roli zawodowej, bez względu na to, jakie specyficzne są cele i zadania instytucji, w której jest on zatrudniony.

W przypadku rezygnacji z wykonywania zawodu psychologa na rzecz innych ról zawodowych (np. administracyjnych) osoba z wykształceniem psychologicznym nie powinna celowo wykorzystywać związanej z kierunkiem wykształcenia wiedzy oraz umiejętności poznawania ludzi i oddziaływania na nich w sposób niezgodny z etyką zawodową psychologa. Psycholog angażujący się w działalność polityczną nie powinien wykorzystywać prestiżu zawodu psychologa jako argumentu popierającego prezentowane poglądy (Tal a ro w s k a i in. 2008).

Psychologia jest nauką empiryczną, która w regułach postępowania kieruje się podobnymi zasadami jak fizyka, chemia czy biologia. Dysponuje własną metodą badawczą, za pomocą której jest w stanie badać swój przedmiot. Jako nauka empiryczna, której przedmiotem analizy i naukowych dociekań jest człowiek badany przez innego człowieka, posiada charakterystyczne tylko dla siebie osobliwości metodologiczne, które muszą być uwzględniane w trakcie prowadzenia 
badań. Psychologia posługuje się specyficznym językiem badawczym, za pomocą którego formułowane są twierdzenia naukowe i hipotezy badawcze ( $\mathrm{Brze}$ ziński 2000).

Ze względu na prowadzenie badań naukowych i klinicznych z udziałem drugiego człowieka w roli „obiektu badań”, psycholog musi borykać się z problemami etycznymi, które nie dotyczą innych dziedzin naukowych. Do tych problemów etycznych należą m.in. okłamywanie uczestników badania, co do jego prawdziwego celu, lub też wprowadzanie uczestników badania w stan psychicznego i fizycznego dyskomfortu. Ponadto odrębne kwestie prawne wiążą się z udziałem w badaniach psychologicznych dzieci i osób niepełnosprawnych, i wyrażaniem przez nie zgody na udział w badaniu. Dlatego wszystkie reguły związane z prowadzeniem badań przez psychologów zostały zebrane w formie kodeksów etyczno-zawodowych, które regulują zasady postępowania diagnostycznego i badawczego (B rzezińs ki 2000).

Kodeksy etyczne zgodnie nakazują psychologom, aby marginalizowali dyskomfort psychiczny i fizyczny uczestników badań. W celu zachowania tej zasady wybrani autorzy (B e r s c he id i in. 1973) proponują stosowanie trzech etapów postępowania. Pierwszy z nich polega na przedstawieniu pełnego opisu badania osobom, które stanowią grupę reprezentatywną dla populacji objętej planowanymi badaniami. Drugi etap to wyrażenie zgody na udział w nich przez te osoby. $\mathrm{Z}$ kolei trzeci etap proponowanej procedury polega na zebraniu przez psychologa właściwej próby, na której zamierza przeprowadzić badania. Odrębnym rozwiązaniem jest zajmowanie się osobami, które w sposób naturalny znalazły się w sytuacjach trudnych - stresowych i analizowanie ich reakcji. Ponadto można badać grupy ochotników lub „osób specjalnych”: strażaków, policjantów, komandosów, którzy z racji pełnionych funkcji zawodowych przyzwyczajeni są do przewlekłe trwających sytuacji niebezpieczeństwa i dyskomfortu. Należy jednak pamiętać o problemie reprezentatywności ich zachowań w stosunku do zachowań tzw. ludzi z ulicy (Brzeziński 2000).

Praca z pacjentem jest niewątpliwie główną dziedziną aktywności zawodowej psychologa. Badania psychologiczne w medycynie odgrywają coraz większą rolę, a czynniki psychologiczne stanowią podstawę każdej pracy z pacjentem. Ich rola w procesie choroby, zwłaszcza choroby przewlekłej oraz w przebiegu i skuteczności terapii jest ogromna, lecz ciągle mało doceniana (K a p l u n 1997; Skłod ow ski, red. 1996; Z boralski i in. 2008). Świadomość potrzeby korzystania przez lekarzy z wiedzy psychologicznej istniała w kręgach medycznych od bardzo dawna. Zastosowanie psychologii w medycynie określane jest jako badanie psychologicznych aspektów powstawania, przebiegu i leczenia chorób mieszczących się $\mathrm{w}$ sferze procesów psychicznych, osobowości i zachowania człowieka (Wrześni ew ski 2005). Psycholog jest osobą przekazującą określoną wiedzę lekarzowi po to, by ten mógł uwzględnić psychologiczne aspekty choroby, leczenia i wzajemnej relacji lekarz - pacjent. Medycyna, jeśli ma speł- 
niać swoje zadania i osiągnąć sukces, powinna korzystać z dorobku psychologii. Wymusiły to zarówno zmiany społeczne, jak i zmiana w strukturze chorób i sposobach ich leczenia.

Obserwując znaczenie i miejsce psychologii w medycynie na przestrzeni kilkudziesięciu lat, dostrzega się wyraźny wzrost zainteresowania i rangi tej dziedziny wiedzy, a także wzrost zatrudnienia psychologów pracujących z chorymi na oddziałach psychiatrycznych i somatycznych i podejmowanie przez nich pracy $\mathrm{w}$ coraz to nowych dziedzinach medycyny. Ważną przyczyną tego zjawiska jest zmiana charakteru chorób i powody zgonów obserwowane w minionym wieku. Na początku XX w. dominowały choroby zakaźne (tyfus, grypa, gruźlica), które często wywoływały epidemie wśród ludności. Z kolei w drugiej połowie XX stulecia na plan pierwszy przyczyn zgonów wysunęly się choroby zwane cywilizacyjnymi (choroby nowotworowe, choroby układu krążenia, udary mózgu oraz wypadki). W sposób zasadniczy podniosło to znaczenie psychologii, która zwraca uwagę na psychospołeczne uwarunkowania występujące szczególnie w tego typu chorobach (B ory s 2006).

Drugim powodem wzrostu znaczenia psychologii w medycynie jest paradoks związany z gwałtownym rozwojem współczesnej medycyny. Postęp w leczeniu, wprowadzenie nowoczesnych metod diagnostycznych i terapeutycznych, a tym samym wzrost technicyzacji, biurokracji i dehumanizacji, spowodowały sprowadzenie pacjenta do roli bezosobowego obiektu badań i pozycji statystycznej. Psychologia jest tą dziedziną wiedzy, a psycholog tym członkiem zespołu badawczego i terapeutycznego, którego zadaniem jest przypominanie i dbanie o podmiotowy charakter chorego człowieka (B o r y s 2006).

$\mathrm{W}$ pracy klinicznej oraz na użytek badań naukowych psycholog, chcąc uzyskać niezbędne dane w relacji z osobą badaną (klientem/pacjentem lub uczestnikiem badania), wykorzystuje podstawową umiejętność praktyczną - diagnozę. Dojście do niej jest procesem aktywnego poszukiwania i identyfikowania informacji potrzebnych do podjęcia decyzji o działaniu zmierzającym do zmiany aktualnego stanu psychospołecznego ludzi. Istotę różnicy między badaniem dla celów naukowych a badaniem dla celów praktycznych nie stanowi odmienność procedury, ale rodzaj zmiennych uznawanych za ważne dla tego zjawiska (P a l u c h o w ski, Hornowska 2000).

Proces diagnozy tworzony jest zawsze przez kogoś i dla kogoś, dlatego nie istnieją badania wolne od wartościowania i problemów etycznych, wyrażają bowiem określone intencje. Psycholog powinien pamiętać o tym, że w sytuacji konfliktu między obowiązkami zawodowymi a wartościami moralnymi, diagnozowanie staje się naruszeniem dóbr osobistych jednostki. Osoby badane wyrażają zazwyczaj zgodę na naruszanie ich intymności, tajemnicy osobistej, tajemnicy korespondencji itp., co nie zwalnia osoby badacza od rozważnego korzystania z tej zgody. Psycholog powinien unikać postawy określanej jako „psychologiczne plotkarstwo”, oznaczającej tendencję do zbierania maksymalnej ilości danych diagnostycznych, 
wykraczającej poza niezbędne potrzeby badania. Należy pamiętać o istotnych kryteriach oceny jakości profesjonalnych działań psychologów: odpowiedzialności za osobę badaną, szacunku dla jej autonomii, branie pod uwagę jej dobra, dobra instytucji, w której się pracuje, społeczeństwa i poszanowania obowiązującego prawa. Innym problemem wynikającym z niedojrzałości psychologii i prowadzonych badań jest brak zgodności wydawanych przez klinicystów ocen czyjegoś stanu psychicznego. Rozbieżność tych opinii może być spowodowana różnicami w sposobie przetwarzania informacji i w klinicznym wnioskowaniu, a także różnicami w uwarunkowaniach osobistych i środowiskowych, które wpływają na spostrzeganie innych ludzi. Hunt (1946, za: P a lu chows ki, H or n ow ska 2000) uważa, że psycholog jako badacz i klinicysta sam w sobie jest podstawowym narzędziem badawczym. Jeśli w procesie diagnozy cechuje go niska trafność i rzetelność, powinien być eliminowany jak nieskuteczny test. Dlatego kształceniu diagnostów powinno poświęcić się tyle uwagi, co tworzeniu dobrych testów.

\section{PSYCHOLOG BADACZ - WYBRANE PROBLEMY ETYCZNE}

Psychologia jest nauką mającą długie dzieje, ale krótką historię. Pomimo że zagadnienia, którymi się zajmuje, były znane i badane od wieków (m.in. w ramach takich nauk, jak filozofia i medycyna), pierwsze laboratorium psychologii eksperymentalnej utworzone zostało dopiero w 1879 r. przez Wilhelma Wundta. Od tego momentu datuje się początek psychologii jako dyscypliny naukowej (Stachowski 2000; Zi mbardo, Ruch 1994). Psychologia naukowa istnieje już ponad 130 lat. Także początków polskiej psychologii należy doszukiwać się w tym samym okresie historycznym (P i e te r 1972). W roku 1903 na Uniwersytecie Jagiellońskim utworzono pierwszą pracownię psychologii eksperymentalnej. Podobne ośrodki powstały wkrótce na Uniwersytecie Lwowskim (1907) oraz na Uniwersytecie Warszawskim (1915). Okres dwudziestolecia międzywojennego przypada na gwałtowny rozwój nie tylko psychologii teoretycznej, ale także psychologii stosowanej. Po wyzwoleniu wznowiły działalność istniejące przed wojną uniwersyteckie katedry psychologii oraz powstały nowe ośrodki (we Wrocławiu, w Lublinie, Poznaniu i Łodzi) (S t a c how ski 2000; B o b r o w s k a-N ow a k 1973). W tej ostatniej, utworzona została w roku 1919 pierwsza na ziemiach polskich Miejska Pracownia Psychologiczna (S k ł o d ow ski, Rytych 2006). W 1948 r. powołano do życia Polskie Towarzystwo Psychologiczne (PTP) z siedzibą w Poznaniu. Jednak po 1948 r. przyszła fala marksistowskiej krytyki psychologii i psychologów, zostały wstrzymane na kilka lat przyjęcia na studia psychologiczne (jedynie na Uniwersytecie Warszawskim nadal wykładano psychologię). W literaturze psychologicznej przeważały przekłady z języka rosyjskiego (S t a c h ow s k i 2000). W okresie stalinowskim za- 
wód psychologa praktycznie został wyeliminowany, a sama psychologia pełniła jedynie funkcje subsydiarne wobec innych dyscyplin naukowych ( $\mathrm{Sk}$ o d ow $\mathrm{ski}$, Rytych 2006). Nauki psychologiczne ponownie rozwinęly się w ramach działalności PTP dopiero na przełomie lat 50. i 60. ubiegłego wieku, a na Uniwersytecie Łódzkim w roku akademickim 1972/1973 uruchomiono samodzielne studia psychologiczne (N i e m c zy ń s ki 2002; S kłod ow sk i-R y ty c h 2006; Brzezińska, Brzeziński, Eliasz, red. 2000).

Już pod koniec XIX w. pojawiły się na ziemiach polskich pierwsze organizacje zrzeszające psychologów. Taką instytucją była założona w $1891 \mathrm{r}$. Sekcja Psychologiczna, działająca w ramach Polskiego Towarzystwa Lekarskiego we Lwowie. Działalność psychologiczną propagowało także Polskie Towarzystwo Filozoficzne we Lwowie, wydając „Badania Psychologiczne”. Od 1907 r. zaczynają organizować się psychologowie na ziemiach zaboru rosyjskiego. Powstaje wówczas Polskie Towarzystwo Psychologiczne w Warszawie oraz Polskie Towarzystwo Badań nad Dziećmi. Dla tych stowarzyszeń działalność psychologiczna nie była jednak aktywnością priorytetową. Dopiero w 1929 r. Stefan Szuman założył Towarzystwo Psychologiczne im. Edwarda Abramowskiego, a Stefan Błachowski powołał do życia Polskie Towarzystwo Psychologiczne. Po wybuchu II wojny światowej ze względu na politykę eksterminacji środowisk naukowych wszelkie organizacje psychologiczne zostały zamknięte. Po wojnie pierwszą organizacją ogólnopolską skupiającą psychologów było założone w 1948 r. przez Stefana Bałachowskiego PTP (P i e te r 1972). Oddział Łódzki PTP utworzono 21 października 1949 r., a na jego czele stanął prof. Albert Dryjski (Skłodowski, Rytych 2006).

Przez długie lata zarówno ci, którzy zawód psychologa wykonywali, jak i ci, którzy z pomocy psychologów korzystali, pozostawali bez ochrony prawnej (Niemczyński 2002). Dzięki zabiegom PTP pojawiła ustawa z 8 czerwca 2001 r. o zawodzie psychologa i samorządzie zawodowym psychologów. Początkowo miała ona wejść w życie 1 stycznia 2002 r., jednak ostatecznie nastąpiło to 1 stycznia 2006 r. Ustawa ta jest jednak aktem „martwym”, ponieważ do chwili obecnej brakuje przepisów wykonawczych regulujących jej postanowienia.

\section{ETYKA ZAWODOWA - POJECCIE}

Etyki zawodowe wyznaczają wzory zachowań dla osób wykonujących dany zawód (Brzeziński, To e plitz-Wini ews ka, red. 2000). Cecha ta powiązana jest z szeroko rozumianą „misją” niektórych profesji (przede wszystkim tzw. wolnych), która utożsamiana jest ze szczególnym zaufaniem oraz osobistym charakterem relacji między przedstawicielem tego zawodu a jego klientem ( $\mathrm{J}$ a c y s z y n 2004).

Usługi wykonywane przez psychologa są zawsze adresowane do konkretnych, indywidualnych osób. Powstaje wówczas intymna więź, oparta na wzajemnym 
zaufaniu i poufności, co do treści wzajemnych kontaktów (B e d n a re k 2002). Relacja ta będzie jeszcze bardziej widoczna, gdy uświadomimy sobie na czym polega zadanie psychologów. Jest nim bowiem poznanie właściwości psychologicznych pacjenta, wyjaśnianie przyczyn zaburzeń i poszukiwanie możliwości ich usunięcia, udoskonalenie procesów regulacji stosunków człowieka ze światem zewnętrznym, ukazanie możliwości i granic rozwoju psychicznego jednostek, określenie warunków zapewniających optymalny rozwój oraz poszukiwanie metod i sposobów, za pomocą których można zapobiegać powstawaniu zaburzeń i dysfunkcji w toku działania oraz przywracać równowagę psychiczną, gdy zostanie naruszona (R e y k o w s k i 1999).

W art. 8, pkt 5 Statutu... (2007) PTP stwierdza się, iż celem jego działania jest

ochrona profesji i etosu psychologa wyrażająca się troską o poziom etyczny i merytoryczny wykonywania praktyki psychologicznej oraz dbałością o interesy osób korzystających z usług psychologicznych lub poddawanych innym oddziaływaniom psychologicznym.

Nadzór nad przestrzeganiem zasad etyki zawodowej psychologa (zgodnie $\mathrm{z}$ art. 33, ust. 2 ustawy o zawodzie psychologa) powinien należeć do zadań samorządu psychologów.

\section{TAJEMNICA ZAWODOWA}

Osoby wykonujące zawód psychologa są zobowiązane do przestrzegania tajemnicy zawodowej, która ma na celu ochronę prawa do prywatności ich klientów i jest gwarancją poszanowania życia prywatnego tych osób (S tepulak 2000). Psycholog ma obowiązek zachowania w tajemnicy informacji związanych z klientem, uzyskanych w związku z wykonywaniem zawodu. Obowiązek ten nie może być ograniczony w czasie (art. 14, ust. 1 i 2 ustawy o zawodzie psychologa). Możliwe wyłączenia tego obowiązku przewiduje jedynie art. 14, ust. 3 wyżej wymienionej ustawy, w odniesieniu do sytuacji zagrożenia zdrowia, życia klienta lub innych osób oraz w przypadku, gdy tak stanowią odrębne ustawy.

Zapis dotyczący tajemnicy zawodowej obecny jest także w Ustawie z dnia 19 sierpnia 1994 r. o ochronie zdrowia psychicznego. Dotyczy ona pracowników służb medycznych, w tym także psychologów. Jej art. 50, ust. 1 brzmi: „Osoby wykonujące czynności wynikające $\mathrm{z}$ niniejszej ustawy są obowiązane do zachowania w tajemnicy wszystkiego, o czym powezmą wiadomość w związku z wykonywaniem tych czynności, stosownie do odrębnych przepisów [...]". W ustępie 2, art. 50 wyżej wymienionej ustawy podaje natomiast okoliczności, w których zwolnienie z obowiązku zachowania tajemnicy zawodowej jest dopuszczalne:

Od obowiązku zachowania tajemnicy osoba wymieniona w ust. 1 jest zwolniona w stosunku do: 1. lekarza sprawującego opiekę nad osobą z zaburzeniami psychicznymi, 2. właściwych organów administracji rządowej lub samorządowej, co do okoliczności, których ujawnienie 
jest niezbędne do wykonywania zadań z zakresu pomocy społecznej, 3. osób współuczestniczących w wykonywaniu czynności w ramach pomocy społecznej, w zakresie, w jakim to jest niezbędne, 4. służb ochrony państwa i ich upoważnionych pisemnie funkcjonariuszy lub żołnierzy w zakresie niezbędnym do przeprowadzenia postępowania sprawdzającego na podstawie przepisów o ochronie informacji niejawnych.

Uregulowania dotyczące zachowania tajemnicy zawodowej opisane są także szeroko w KEZ. Zgodnie z jego postanowieniami, psychologa obowiązuje przestrzeganie tajemnicy zawodowej. Ujawnienie wiadomości objętych tajemnicą zawodową może nastąpić jedynie wtedy, gdy poważnie zagrożone jest bezpieczeństwo klienta lub innych osób. Jeśli jest to możliwe, decyzję w tej sprawie należy dokładnie omówić z doświadczonym i bezstronnym kolegą. Materiały poufne powinny być komisyjnie zniszczone, jeżeli zaistnieją warunki grożące ich ujawnieniem (art. 21). Wnikanie w intymne, osobiste sprawy klienta dopuszczalne jest jedynie w takim zakresie, jaki wynika z celów pomocy psychologicznej (art. 22). Współpracując ze specjalistami z innych dziedzin lub korzystając z ich konsultacji (tj. wykonując badanie na ich zlecenie), psycholog udostępnia wyniki własnych badań tylko w takim stopniu, w jakim jest to potrzebne. Informuje przy tym o konieczności utrzymania tych danych w tajemnicy (art. 23). Korzystając z pomocy personelu pomocniczego bez pełnych kwalifikacji (np. studenci, pielęgniarki itp.) psycholog odpowiada za realizację zasad etyki zawodowej, a w szczególności powiadamia asystentów o obowiązku bezwzględnego przestrzegania tajemnicy zawodowej, z wyjątkiem zagrożenia bezpieczeństwa osób, a „materiały powierzone [...] do opracowania zabezpiecza w miarę możliwości przed imienną identyfikacją" (art. 24).

\section{UZYSKANIE ZGODY OSOBY BADANEJ}

Psycholog ma obowiązek uzyskać zgodę klienta/pacjenta na poddanie ich diagnozie lub też innym oddziaływaniom psychologicznym (art. 12 Ustawy z dnia 8 czerwca 2001 r. o zawodzie psychologa i samorzadzie zawodowym psychologów). Tak rozumiana zgoda jest warunkiem legalności działań podejmowanych w procesie świadczenia usług medycznych i nie jest najważniejsze, co chory lub jego rodzina pragną wiedzieć o stanie zdrowia, ale chodzi o to, co wiedzieć powinni. Sam brak sprzeciwu pacjenta nie wydaje się wystarczający (L i s z e w s k a 1997). Ten obowiązek może być uchylony jedynie przez wyraźne oświadczenie pacjenta, że nie chce on być informowany o swoim stanie zdrowia, a także $\mathrm{w}$ sytuacji, gdy ograniczenie informacji uzasadnione jest według oceny lekarza stanem zdrowia pacjenta (art. 31, ust. 4 Ustawy z dnia 5 grudnia 1996 r. o zawodzie lekarza).

Obowiązek informowania chorego dotyczy także pacjentów, którzy ukończyli 16 lat. Jeżeli pacjent nie ukończył tego wieku lub jest nieprzytomny bądź 
niezdolny do zrozumienia znaczenia informacji, lekarz udziela jej przedstawicielowi ustawowemu, a w razie jego braku lub gdy porozumienie się z nim jest niemożliwe - opiekunowi faktycznemu pacjenta lub sądowi opiekuńczemu. Pacjentowi małoletniemu lekarz udziela informacji w zakresie i formie potrzebnej do prawidłowego przebiegu procesu diagnostycznego lub terapeutycznego i wysłuchuje jego zdania. W takim przypadku, zgodę na przeprowadzenie badania może wyrazić także opiekun faktyczny chorego. W przypadku osoby całkowicie ubezwłasnowolnionej zgodę na badania wyraża przedstawiciel ustawowy tej osoby. Jeżeli osoba taka jest $\mathrm{w}$ stanie $\mathrm{z}$ rozeznaniem wypowiedzieć opinię $\mathrm{w}$ sprawie badania, konieczne jest ponadto uzyskanie zgody tej osoby. W przypadku badanych, którzy ukończyli 16 lat, wymagana jest także ich zgoda. Jeżeli jednak małoletni, który ukończył 16 lat, osoba ubezwłasnowolniona albo pacjent chory psychicznie lub upośledzony umysłowo, lecz dysponujący dostatecznym rozeznaniem, sprzeciwia się czynnościom medycznym, poza zgodą jego przedstawiciela ustawowego lub opiekuna faktycznego albo w przypadku niewyrażenia przez nich zgody, wymagana jest zgoda sądu opiekuńczego (art. 32 Obwieszczenia... 2005).

Prawo pacjenta do wyrażenia zgody na udzielenie określonych świadczeń zdrowotnych ma szczególne znaczenie w odniesieniu do osób z zaburzeniami psychicznymi (P o n c z e k 2000). Specyfiką psychiatrii jest bowiem konieczność postępowania przymusowego, w przypadku którego istnieje szczególnie duże zagrożenie dla godności człowieka i jego prawa samostanowienia (B o r a ty ń s k a, K o n i e c zn i a 2001). Zagadnienie uzyskania zgody jako przesłanki legalności udzielenia świadczeń zdrowotnych w odniesieniu do osób z zaburzeniami psychicznymi regulują przepisy Ustawy z dnia 19 sierpnia 1994 r. o ochronie zdrowia psychicznego (art. 21, art. 22, art. 23, art. 29).

Psycholog ma obowiązek poinformować klienta o celu podejmowanego postępowania, jego przebiegu, wynikach i sposobie ich udostępniania oraz powinien uzyskać akceptację planowanych czynności (art. 13 ustawy o zawodzie psychologa). Kodeks Etyczno-Zawodowy Psychologa... (1991, pkt 16-20 oraz pkt 34) także zawiera regulacje dotyczące omawianego zagadnienia. Zgodnie z nimi, psycholog powinien poinformować klienta o ewentualnym ryzyku związanym ze stosowanymi metodami terapeutycznymi oraz o istniejących metodach alternatywnych, z uwzględnieniem metod niepsychologicznych. Rozpoczynając pracę, psycholog każdorazowo uzgadnia z klientem cel i zakres swoich oddziaływań oraz zasadnicze sposoby postępowania. Ustalenia te mają charakter wstępny i mogą ulec zmianie w toku dalszych kontaktów. W przypadku istnienia niezgodności poglądów należy dążyć do uzgodnienia jednolitego stanowiska. Osoby zgłaszające się do psychologa nie z własnej inicjatywy, zarówno dorośli, jak i dzieci, powinny być przez niego informowane o celu postępowania, stosowanych metodach, wynikach i sposobie ich udostępnienia. Psycholog stara się uzyskać akceptację planowanych czynności zawodowych przez te osoby. Osoby 
małoletnie powinny być traktowane w sposób szczególny. Podstawową zasadą psychologa w pracy z osobami małoletnimi jest ich dobro, co oznacza, że osoby te w kontaktach z psychologiem mają prawa nie mniejsze niż klienci dorośli. Kontakty z psychologiem w żadnym razie nie mogą być realizowane pod presją ze strony instytucji i osób dorosłych decydujących w imieniu małoletniego. W takim przypadku oraz $\mathrm{w}$ razie stwierdzenia naruszenia przez instytucję lub osoby dorosłe dobra małoletniego, psycholog ma prawo odmówić współpracy z tymi instytucjami i osobami. Psycholog ma prawo i też obowiązek respektować decyzję małoletniego jako osoby ludzkiej w zakresie kontaktów z nim (B r z e z iń s k a 2000). Osobom korzystającym z diagnozy i terapii psychologicznej, psycholog udziela informacji o stosowanych metodach i uzyskanych wynikach, kierując się dobrem tych osób. Psycholog unika postępowania stwarzającego ryzyko zagrożenia wartości cenionych przez klienta, a także okazji do błędnej interpretacji podawanych informacji. W wypadkach wątpliwych psycholog upewnia się, czy informacje zostały właściwie zrozumiane (Ta la r o w s k a 2009).

\section{PSYCHOLOG JAKO BADACZ}

Od problemów etycznych nie jest wolny psycholog występujący w roli badacza. Jedna z kwestii dotyczy upubliczniania wyników przeprowadzanych badań. Psycholog w roli badacza powinien zdawać sobie sprawę z tego, że wyniki badań naukowych nie tylko stanowią poszerzenie obszaru ludzkiej wiedzy, lecz mogą także być wykorzystane w praktyce społecznej. Podejmując badania naukowe psycholog starannie rozważa ich stronę etyczną, a zwłaszcza możliwe pozytywne i negatywne konsekwencje udostępnienia wyników badań i ich wykorzystania w praktyce społecznej (art. 29 KEZ). Psycholog prowadzący badania naukowe powinien podejmować tematy zgodne z wartościami etycznymi swojej profesji, odpowiadać za dobór metod badawczych umożliwiających uzyskanie wiarygodnych wyników i za rzetelne przedstawienie rezultatów badań. W tym zakresie psycholog nie powinien ulegać presji osób ani okoliczności (art. $30 \mathrm{KEZ).} \mathrm{Podej-}$ mując badania z udziałem ludzi, psycholog starannie rozważa zgodność planowanego przedsięwzięcia z ogólnymi zasadami etyki zawodowej. Osoby pracujące pod czyimś kierunkiem również ponoszą odpowiedzialność za stronę etyczną badań w tym zakresie, w jakim zależy to od ich własnej decyzji (art. $31 \mathrm{KEZ).}$ Psycholog przestrzega zasady dobrowolności uczestniczenia w badaniach psychologicznych, a także respektuje prawo uczestników do wycofania się w dowolnym momencie $\mathrm{z}$ dalszego udziału w badaniach. Jeżeli uczestnicy badań pozostają w stosunku zależności wobec prowadzącego badania jako jego studenci, klienci lub pracownicy, a także wtedy, gdy istnieje możliwość społecznej presji na udział w badaniach, należy szczególnie zadbać o to, aby zasada dobrowolnego udziału nie była naruszona (art. $32 \mathrm{KEZ).} \mathrm{Psycholog} \mathrm{nie} \mathrm{podejmuje} \mathrm{badań,} \mathrm{które} \mathrm{mogłyby}$ 
narazić osoby uczestniczące na cierpienia lub utratę cenionych wartości. Jeżeli ważne względy poznawcze i praktyczne przemawiają za przeprowadzeniem tego rodzaju badań i nie istnieją inne sposoby uzyskania danych, należy bezstronnie rozważyć, czy spodziewane korzyści z badań uzasadniają i usprawiedliwiają ich prowadzenie (art. 33 KEZ).

Przed uzyskaniem zgody na udział w badaniach należy w takich wypadkach szczególnie starannie poinformować przyszłych uczestników o ich przebiegu. Uczestnikami takich badań nie mogą być osoby pozostające w stosunku zależności wobec prowadzącego badania. Psycholog zobowiązany jest również podjąć wszelkie dostępne kroki w celu zminimalizowania przykrości związanych z badaniami i ich negatywnych skutków dla osób uczestniczących (art. 33 KEZ). Przed rozpoczęciem badań psycholog ma obowiązek poinformowania uczestników o ich celu, przebiegu, a zwłaszcza o tych aspektach badania, co do których w sposób uzasadniony można oczekiwać, że będą wpływać na gotowość uczestniczenia oraz wyjaśnić wszystkie inne aspekty badania, o które pytają uczestnicy i uzyskać ich zgodę. Jeżeli planuje się zastosowanie urządzeń rejestrujących zachowanie uczestników badań (kamera, magnetofon albo obserwacja z ukrycia) bezwzględnie należy o tym poinformować badanych i uzyskać ich zgodę. Dotyczy to zarówno dorosłych, jak i dzieci. W wyjątkowych wypadkach informację te można przekazać po zakończeniu badań, należy jednak wtedy zapewnić badanym możliwość odmowy zgody na wykorzystanie uzyskanych od nich danych (art. 34 KEZ) (zobacz także art. 39 Konstytucji... 1997: ,[...] nikt nie może być poddany eksperymentom naukowym, w tym medycznym, bez dobrowolnie wyrażonej zgody").

Psychologowi-badaczowi nie wolno, nawet $\mathrm{w}$ imię naukowej prawdy lub dobra społecznego, ujawniać tajemnicy zawodowej w odniesieniu do poszczególnych badanych osób (S t e p ulak 2000). W art. 35 cytowanego wyżej KEZ uznano, że w każdym przypadku powoływania się na konkretne wyniki badań psycholog usuwa z nich wszystko, co mogłoby się przyczynić do identyfikacji osób uczestniczących.

Posługując się w badaniach zwierzętami, psycholog unika zadawania im cierpień. Jeśli ze względu na szczególnie ważne cele badawcze cierpienie zwierzęcia jest nie do uniknięcia, psycholog usilnie dąży do jego złagodzenia (art. 36 KEZ).

Pycholog dba o rzetelne przedstawienie wyników swych badań i stara się zapobiec ich niewłaściwemu wykorzystaniu. Dlatego należy zawsze uwzględniać wyniki, które nie potwierdzają hipotez badawczych, istnienie alternatywnych hipotez i alternatywnych sposobów interpretacji wyników oraz ograniczenia zasięgu generalizacji uzyskanych rezultatów. Szczególną ostrożność należy zachować przy formułowaniu praktycznych wniosków z badań (art. 37 KEZ). Psychologa obowiązuje prawdziwe i wyczerpujące informowanie o źródłach, z których korzystał. Psycholog nie zataja, że korzystał w swoich publikacjach lub pracach badawczych z materiałów innych autorów oraz z pomocy i konsultacji innych osób 
(art. $38 \mathrm{KEZ).} \mathrm{Uczestnicząc} \mathrm{w} \mathrm{pracach} \mathrm{zespołowych,} \mathrm{psycholog} \mathrm{respektuje} \mathrm{prawa}$ autorskie innych członków zespołu i dba o ochronę własnych praw autorskich. Zasada ta jest szczególnie ważna przy prowadzeniu badań interdyscyplinarnych (art. 39 KEZ). Psycholog nie firmuje swoim nazwiskiem żadnych publikacji lub prac, w których nie brał udziału, ani nie przedstawia swojego udziału w sposób niezgodny z rzeczywistym wkładem wniesionym w te prace (art. $40 \mathrm{KEZ}$ ). Psycholog opiniujący prace badawcze innych autorów zdaje sobie sprawę ze znaczenia krytyki naukowej w rozwoju dyscypliny i ciążącej na nim osobistej odpowiedzialności za rzetelność wydawanych ocen. Psycholog nie podejmuje ocen pracy, jeśli istnieją okoliczności uniemożliwiające wydanie bezstronnej, rzetelnej i kompetentnej oceny (art. $41 \mathrm{KEZ}$ ).

Psycholog jako członek społeczności akademickiej realizuje naczelne wartości etyczne swojego zawodu, takie jak godność, podmiotowość i autonomia człowieka. W kontaktach z przedstawicielami innych dziedzin nauki stara się upowszechniać typ relacji oparty na tych wartościach (art. $42 \mathrm{KEZ}$ ).

Zasady Kodeksu Etyczno-Zawodowego Psychologa... (1991) obowiązują wszystkich polskich psychologów. Wstępując do Polskiego Towarzystwa Psychologicznego, psycholog przyjmuje na siebie zobowiązanie skrupulatnego przestrzegania zasad Kodeksu Etyczno-Zawodowego Psychologa i upowszechniania ich wśród psychologów niezrzeszonych w PTP. Postępowanie członka PTP sprzeczne z Kodeksem Etyczno-Zawodowym pociąga za sobą sankcje, o których orzeka Sąd Koleżeński (art. 50 KEZ).

\title{
PROBLEMY W RELACJI Z PACJENTEM W CHOROBIE TERMINALNEJ I JEGO RODZINA
}

\begin{abstract}
Jeśli indywidualne życie ludzkie jest ciągłym procesem, to istnieje w nim zawsze pewien punkt, od którego zaczyna się jego powolna dezintegracja. Wchodzimy w smugę cienia powoli, nie zdając sobie nawet z tego sprawy, a później pozostaje nam jedynie mniej lub bardziej beznamiętna rejestracja kolejnych objawów starzenia się i moment, kiedy przechodzimy do klasy byłych osób.
\end{abstract}

(S z a w a rski 2005: 267).

Życie ludzkie jest procesem, w którym możemy wyróżnić różne okresy, ale zawsze ma swój początek i koniec. Pomiędzy tymi dwoma okresami następuje szereg przemian zarówno pozytywnych, jak i negatywnych. Wszyscy jednak jesteśmy śmiertelni, a śmierć z reguły jest następstwem nieuleczalnej choroby.

Problemy psychologiczne człowieka ciężko chorego, chorego śmiertelnie, a szczególnie w okresie terminalnym, należą do jednych z najtrudniejszych. Nie miejsce tutaj na szczegółowe przedstawianie definicji i różnic terminologicznych. Mimo to musimy wiedzieć, że o chorobie terminalnej mówimy wówczas, gdy 
leczenie zasadnicze nie przynosi już pożądanego skutku w postaci ustąpienia choroby i można zastosować jedynie leczenie objawowe. Możemy zatem mówić o stanie terminalnym choroby śmiertelnej. Dla porządku jednak należy wspomnieć, że w rozumieniu potocznym terminy: choroba terminalna czy śmiertelna są najczęściej ze sobą utożsamiane.

Aby pokazać jakość i ogrom trudności, jakie może napotkać badacz wobec chorych śmiertelnie (a szczególnie chorych terminalnie), musimy w pierwszej kolejności wspomnieć o psychologicznych reakcjach na wystąpienie choroby, w tym choroby śmiertelnej. Następnie powinniśmy rozważyć problem poprawnej komunikacji z pacjentem, poznać jego rozumienie sytuacji, w której się znalazł, oczekiwania, nadzieje.

W codziennym życiu z reguły nikt nie myśli o możliwości wystąpienia zaburzeń lub choroby. $Z$ uwagi na olbrzymią liczbę spraw, z którymi każdego dnia mamy do czynienia, problem własnego zdrowia schodzi na plan dalszy. Sytuacja znacznie komplikuje się, gdy zostaje zaburzona równowaga w funkcjonowaniu naszego organizmu spowodowana wystąpieniem poważnej choroby. Wówczas stajemy przed sytuacją, która jest dla nas zupełnie nowa, a dodatkowo stresująca. Choroba stanowi dla nas zawsze większe lub mniejsze obciążenie psychiczne.

Musimy zdawać sobie sprawę, że chory spostrzegając chorobę, jednocześnie przypisuje jej określone znaczenie, nadaje jej sens. Zdaniem Heszen-Niejodek pacjent chorobę najczęściej postrzega jako zagrożenie, przeszkodę, stratę, krzywdę, karę, czasem nawet jako pewną wartość, korzyść, ulgę (H e s ze n-N i ej od ek 2005). Obserwacje pokazują, że najczęściej pacjenci widzą w chorobie zagrożenie tych wartości, które cenią najwyżej (głównie zdrowia i życia). Poczucie zagrożenia wzrasta w przypadku choroby przewlekłej o ciężkim przebiegu i takiej, której rokowanie według wiedzy chorego jest złe. Kiedy choroba spostrzegana jest jako przeszkoda, dochodzi do frustracji różnych potrzeb. Jeżeli chory posiada wiarę w wyleczenie, wówczas dysfunkcja staje się wyzwaniem. Takie postrzeganie choroby z punktu widzenia terapeutycznego jest szczególnie istotne w procesie leczenia (J a k u b o w s k a-W in i e c k a, W ł o d a r c z y k, red. 2007).

Choroba o ciężkim i długotrwałym przebiegu może być postrzegana jako strata (krzywda). Zjawisko to jest uwarunkowane stanami związanymi z zagrożeniem trwałą utratą zdrowia lub kalectwem. Utrudnienia w pełnieniu określonych społecznych ról lub pozbawienie możliwości zarobkowania sprawiają, że pacjenci wprost zadają pytanie o powody i przyczyny pojawienia się choroby („Co zrobiłem złego w życiu, że spotkała mnie choroba?"). Traktowanie choroby, jako krzywdy lub straty powoduje, że postrzegamy ją jako karę za własne lub cudze przewinienia i grzechy. Taka postawa pacjenta może mieć charakter przejściowy. Wówczas jest on zdolny dokonać pozytywnych przewartościowań i w konsekwencji podjąć wysiłek, aby walczyć o zdrowie. Jeżeli jednak wspomniana postawa jest wynikiem wewnętrznego przekonania, zgodnie z którym choroba 
jest zasłużoną karą, wówczas staje się ona istotną przeszkodą w walce o życie (J a kubowska-Wini ecka, W ło d a rczyk, red. 2007). W przeciwieństwie do powyższych, traktowanie choroby jako ulgi czy korzyści może być dla pacjenta źródłem pozytywnych emocji. W pewnych przypadkach choroba bywa wymówką dla osoby, która pragnie uzyskać określony zysk materialny lub pozycję społeczną. Choroby zagrażające życiu mogą okazać się dla niektórych „dobrem”, wartością, pozwalającą wejść na wyższy poziom duchowy. Pacjent z cierpienia wynosi lekcję dla samego siebie, podnoszącą jego samoocenę, pozwalającą na samoakceptację.

Postawy i reakcje wobec choroby bywają rozmaite i są uzależnione od wielu czynników, m.in. od rodzaju i charakteru schorzenia (np. umiejscowienie), rokowań (obiektywnych i subiektywnych), możliwości leczenia, dostępności do lekarza, spostrzeganych korzyści lub strat w obliczu choroby, subiektywnego obrazu, jaki chory tworzy wobec swojej sytuacji związanej z chorobą. Czynniki psychologiczne należą do tych zmiennych, które stanowią niezwykle ważny element w radzeniu sobie z chorobą. Do nich możemy zaliczyć tzw. zasoby osobiste (wiedza, doświadczenie, cechy osobowości) oraz zasoby zewnętrzne (sytuacja społeczno-ekonomiczna, wsparcie ze strony innych itp.) (Jakubowska-Winiecka, Włod arczyk, red. 2007).

W przypadku wystąpienia choroby, która obiektywnie czy w subiektywnej opinii pacjenta jest śmiertelna, najczęściej pojawia się lęk. Potocznie o lęku mówi się jako o objawie, ale lęk jest zespołem wielu objawów psychologicznych i fizjologicznych (np. poczucie braku bezpieczeństwa, napięcia emocjonalnego, a także zblednięcie, pojawienie się tzw. „gęsiej skórki”, przyspieszenie oddechu, tętna itp.). Jedną z konsekwencji występowania lęku i spostrzegania choroby jako zagrożenia jest pojawienie się reakcji denial, tzn. reakcji zaprzeczania chorobie. Pojawia się ona w wyniku dość skomplikowanego procesu psychologicznego i może prowadzić do różnych konsekwencji, np. niepodejmowania przez pacjenta leczenia lub bagatelizowania swojego stanu. Ta reakcja jednak poprawia psychologiczną sytuację pacjenta - mianowicie obniża poziom lęku.

Podczas prowadzenia rozmowy z takim pacjentem musimy zdawać sobie sprawę, że informacje, które nam przekazuje, mogą być w wyniku stosowania reakcji denial zniekształcone.

Opisane powyżej niektóre problemy związane z reakcją na chorobę somatyczną ('́miertelną) związane są z adaptacją pacjenta do nowej sytuacji - sytuacji bycia chorym. W przypadku choroby nieuleczalnej, śmiertelnej adaptacja bywa trudna i jeżeli przebiega w niewłaściwym kierunku (gdy przeważa lęk), mogą się pojawić nawet zachowania wrogie zarówno do osób bezpośrednio związanych z procesem leczenia, jak i innych, również najbliższych.

Kiedy chory dowiaduje się o tym, że jego choroba jest nieuleczalna, śmiertelna, znajduje się w sytuacji szczególnie trudnej. Jego reakcje na taki fakt bywają 
różne: od niedowierzania do głębokiej depresji. O akceptacji choroby, etapach adaptacji pacjentów umierających pisała amerykańska lekarka (pochodząca ze Szwajcarii) dr Elizabeth Kübler-Ross. W wyniku prowadzonych przez nią rozmów ze śmiertelnie chorymi, powstał obraz pięciu stadiów radzenia sobie z zaistniałą sytuacją. Są to kolejno: zaprzeczenie i izolacja, gniew, targowanie się, depresja, pogodzenie się (K ü b l e r-R o s s 1979). Należy podkreślić, że niżej wymienione etapy, jakie przechodzą pacjenci nie zawsze muszą wystąpić wszystkie i w tej kolejności.

1. Zaprzeczenie i izolacja - jest naturalną reakcją organizmu na sytuację, która wydaje się wysoce zagrażająca. Takie zachowanie daje człowiekowi czas potrzebny do zaadaptowania się w nowej sytuacji. Gdy pacjent stwierdzi, że zaprzeczanie przestaje być możliwe, wówczas przechodzi do fazy następnej.

2. Gniew - podczas trwania tej fazy chory wyraża swoje pretensje i wrogość, gniew, złość wobec innych. Może to być Bóg, najbliżsi, koledzy, los, lekarz lub inna osoba $\mathrm{z}$ personelu medycznego. W tej fazie pacjent często w sposób otwarty pragnie uzyskać odpowiedź na pytanie o bezpośrednią przyczynę zachorowania (M ą c z k a 2007). Gniew jest wyrazem potrzeby kontrolowania, ogarnięcia sytuacji, w której chory czuje się całkowicie pozbawiony możliwości wpływu na zdarzenia (S a d o ck, S a d o c k 2003; M ą c zk a 2007).

3. Targowanie się - pacjenci często oferują (głównie zwracając się do Boga) różne rzeczy lub zachowania w nadziei, że zostaną uleczeni. Oczywiste jest, że w pierwszej kolejności zwracają się do Boga, ale także są w stanie oddać wszystko np. temu lekarzowi, który zagwarantuje powrót do zdrowia.

4. Depresja - świadomość nieskuteczności działań na rzecz zdrowia powoduje wycofanie się, rezygnację z dalszej aktywności, poczucie beznadziejności i obniżenie nastroju.

5. Pogodzenie się, akceptacja - w tej fazie chory w pełni zdaje sobie sprawę z nieuchronności śmierci jako konsekwencji swojego stanu oraz jako kolejnego (ostatniego) etapu w życiu każdego człowieka.

Krystyna de Walden-Gałuszko charakteryzując reakcje psychiczne człowieka chorego w stanie terminalnym, uważa, że mogą one przyjąć różną postać:

a) reakcje psychiczne „normalne” - okres terminalny cechuje stopniowa progresja procesu chorobowego (pomimo leczenia), w związku z tym dochodzi do okresowego nasilenia dolegliwości i pojawiania się nowych trudności. Nasilenie objawów fizycznych (szczególnie bólu) wywołuje z reguły: podwyższony lęk, niepokój, przygnębienie, związane jest również z poczuciem osamotnienia, izolacji, upokorzenia;

b) przedłużające się leczenie powoduje, że pacjent zdążył się do swojej sytuacji przyzwyczaić, zaczął sobie z nią radzić, pogodził się z rolą chorego. Informacja ze strony personelu medycznego o odmowie leczenia specjalistycznego 
(komunikat typu: „Nic już się nie da zrobić”) stanowi duży szok dla pacjentów. W odpowiedzi na nią chorzy często reagują dezorganizacją psychiczną wyrażającą się: milczeniem, zahamowaniem, zamknięciem się w sobie lub odwrotnie pobudzeniem i skargami. $U$ innych występuje lęk, gniew, przygnębienie i rozpacz, przeplatane przebłyskami nadziei (W a l d e n-G a ł u s z k o de 2000).

Według Cicely Saunders, chorzy terminalnie kierują do innych trzy główne prośby: „,pomóż mi”, ,,wysłuchaj mnie”, „nie opuszczaj mnie” (O r o ń s k a 2000). Uświadomienie sobie sytuacji nieodwracalności procesu chorobowego i zbliżającej się śmierci następuje powoli, czasem na kilka dni przed nią. Nieświadomość własnego stanu $\mathrm{w}$ wielu przypadkach utrzymuje się do samego końca. Zjawisko to nie jest jednak związane z niewiedzą pacjenta na temat przebiegu choroby, ale jest wynikiem psychologicznego mechanizmu, zgodnie z którym nasze reakcje emocjonalne nie zależą od samych faktów, lecz od naszego subiektywnego wyobrażenia o nich (Wa l d e n-Gału s z k o de 2000).

\section{PROBLEMY W KOMUNIKACJI Z CHORYM ŚMIERTELNIE}

\section{ZASADY PROWADZENIA ROZMOWY}

Procedury badań naukowych są bardzo podobne do rozmowy, spotkania z lekarzem, psychologiem lub inną osobą z zespołu medycznego. Sytuacja spotkania z pacjentem wyznacza specyfikę komunikacji, która nie ma charakteru relacji równoległej. W dalszej kolejności przedstawię zasady prowadzenia rozmowy na przykładzie spotkania chorego z lekarzem. Chory człowiek przychodzi do lekarza (badacza) w sytuacji subiektywnie rozumianej choroby i z tej pozycji z nim rozmawia. Ma w stosunku do tych osób określone oczekiwania. Przede wszystkim oczekuje wyjaśnienia przyczyn swoich dolegliwości, profesjonalnej porady, wsparcia, zrozumienia oraz fachowej pomocy.

W zależności od zachowania i postawy lekarza w tej relacji, pacjent nabiera do niego zaufania lub staje się nieufny i oczekuje szybkiego końca wizyty. Już w procesie diagnostycznym odbywa się swoisty „test”. Lekarz z reguły traktowany jest przez chorego jako osoba mająca autorytet, najważniejsze źródło informacji. Podczas komunikacji z pacjentem może ów autorytet utrzymać, pomnożyć lub stracić. Utrata autorytetu przez lekarza już na etapie diagnozy z reguły kończy się całkowitym niepowodzeniem lub znacznie mniejszymi efektami terapeutycznymi.

O jakości rozmowy decyduje prowadzący. Powinien ją tak poprowadzić, aby to pacjent miał poczucie o swoim wpływie na nią. Rozmowa zwykle powinna rozpoczynać się od wysłuchania pacjenta. Umiejętność aktywnego słuchania wcale nie jest zadaniem łatwym. Chory powinien mieć poczucie, że został wysłuchany. Aktywne słuchanie to nie tylko słuchanie w milczeniu wypowiedzi 
pacjenta. Krzysztof Je dliński (1992) przytacza kilka reguł dotyczących aktywnego słuchania.

1. Być skoncentrowanym na wypowiedziach pacjenta tak, aby był on przekonany o ważności swojego problemu.

2. Natychmiast przerwać w momencie, kiedy pacjent czegoś nie zrozumie i udzielić mu wyjaśnień własnymi słowami.

3. Na dowód tego, że zrozumiał wypowiedź chorego, powinien powtórzyć ją raz lub kilka razy, ewentualnie w drodze refleksji zinterpretować ją.

4. Rozmówca powinien zachowywać się w sposób empatyczny, okazać zrozumienie dla stanu emocjonalnego pacjenta.

Powinniśmy wiedzieć także, że każdy chory niezwykle bacznie obserwuje swojego rozmówcę. W literaturze zwraca się uwagę, że w relacji lekarz - pacjent ok. 7\% siły oddziaływania na odbiorcę stanowi to, co mówimy (przekaz werbalny), a pozostałe ponad $90 \%$ to przekaz niewerbalny. Do niewerbalnych elementów ekspresji możemy zaliczyć m.in.: mimikę twarzy, pozycję, postawę ciała i gesty (inaczej kinezjetykę), odległość, jaka dzieli osoby będące w interakcji (proksemika), a także tzw. parajęzyk, czyli głosowe, ale niewerbalne aspekty porozumiewania się (tempo wypowiedzi, głośność, milczenie, pomyłki językowe, śmiech, ziewanie itd.). Badania wykazują, że chorzy są bardzo wyczuleni na niewerbalne zachowania. Wynika to z faktu, że choroba, szczególnie nowotworowa, jest zawsze stanem, który wywołuje silne emocje (lęk, niepewność, poczucie zagrożenie życia) (C hry s to w s k a-J a błoń sk a 2006).

Komunikacja badacza (lekarza, psychologa, naukowca) z pacjentem musi być wartościowa dla obydwu stron. Jednak do pacjenta należy stwierdzenie, czy informacje jakie uzyskuje są wyczerpujące, wystarczające i zrozumiałe.

W wielu podręcznikach medycyny i psychologii istotność kontaktu z pacjentem chorym śmiertelnie jest szczególnie podkreślana. Nie budzi wątpliwości fakt, że właśnie taki pacjent wymaga szczególnej troski i uwagi. Często jednak z rozmów z lekarzami wyłania się przeciwny obraz. Z jednej strony wskazują oni na potrzebę zdobycia informacji na temat tego, jak informować chorego o chorobie nowotworowej, jak i o czym rozmawiać w sytuacji, gdy chory zna rozpoznanie, co powiedzieć, gdy zapyta, czy umrze, co powiedzieć rodzinie? Jednak z drugiej strony, wielu $\mathrm{z}$ nich unika kontaktu $\mathrm{z}$ takimi pacjentami lub ogranicza go do niezbędnego minimum. $\mathrm{Z}$ obserwacji wynika, że taka postawa najczęściej uwarunkowana jest lękiem i brakiem przygotowania do „spotkania” ze śmiercią. Jeżeli jednak lekarz (badacz) przełamie własne opory, okaże się, że w konfrontacji z pacjentem chorym śmiertelnie, najprostszym rozwiązaniem jest szczera rozmowa, która przynosi olbrzymią ulgę choremu i lekarzowi, a często także członkom rodziny. Charakter komunikacji z pacjentem, szczególnie z tym, u którego rozpoznano chorobę ciężką i przewlekłą, bardzo trafnie scharakteryzował Andrzej Steciwko pisząc: ,[...] w konfrontacji z życiem okazuje się, że umiejętność ko- 
munikowania się jest sztuką i tak jak w sztuce styl, tak i sposób nawiązywania kontaktów lekarza z pacjentem ma różne odcienie" (S te c i w k o 2000: 121).

Typowe trudności, z którymi możemy się spotkać podczas kontaktu z chorymi śmiertelnie, są związane z:

1) nawiązaniem kontaktu $z$ chorym,

2) rzetelnym informowaniem pacjenta,

3) przekazywaniem trudnych informacji, mówieniem prawdy,

4) kontaktem $z$ rodziną i bliskimi pacjenta,

5) radzeniem sobie $\mathrm{z}$ rodzącymi się $\mathrm{w}$ tej sytuacji emocjami, zarówno pacjenta, jak i własnymi (B ę d k ow s ka-K orpała, G i erow s ki 2007).

\section{RODZINA PACJENTA UMIERAJĄCEGO}

Nikt z nas nie jest nigdy przygotowany na odejście kogoś bliskiego. Każda śmierć jest bolesna i chociaż wydaje się nam wówczas, że świat się zawalił, to musimy sobie uświadomić, iż dla chorego często „tak jest lepiej”. Dla wyniszczonego przez chorobę organizmu, śmierć oznacza także koniec cierpienia, koniec niewyobrażalnego, trudnego do złagodzenia bólu, koniec zawstydzających i często upokarzających go odruchów jego ciała, nad którym nie jest już w stanie zapanować. Koniec lęków. Chorzy bardzo często miewają poczucie winy, że stanowią dla rodziny kłopot, że ktoś się dla nich poświęca.

Najtrudniejszym okresem dla chorego (wywołującym najwięcej załamań i rozpaczy) jest okres pierwszego nawrotu choroby. Dla rodziny takim okresem jest stan terminalny. Dużym obciążeniem dla rodziny są także dolegliwości fizyczne chorego, głównie ból i duszność. Silne reakcje emocjonalne u członków rodziny wywołują także zaburzenia psychiczne chorych (majaczenie, zaburzenia zachowania), z którymi wiąże się utrata świadomego kontaktu. Bliscy opiekunowie sprawujący opiekę 24-godzinną są wyczerpani fizycznie i psychicznie. Na rodzaj reakcji emocjonalnych członków rodziny wpływa wiele czynników, jak m.in.: wiek, etap rozwoju rodziny, warunki bytowe, rodzaj i przebieg choroby, możliwość wsparcia ze strony innych członków rodziny.

Członkowie rodziny pacjenta chorego śmiertelnie, a szczególnie w stanie terminalnym, również wymagają wsparcia i rady. Aby poprawić kontakt z chorym, także muszą zaakceptować fakt nieuchronności śmierci i cierpienia. Nie powinni płakać - szczególnie przy chorym (na to jeszcze będą mieli czas), nie powinni okazywać choremu znużenia, zniecierpliwienia, zniechęcenia, aby nie powodować u niego poczucia winy. Powinni do końca traktować go, jak normalnego członka rodziny, tzn. rozmawiać z nim, cieszyć się każdą chwilą spędzoną razem. Starać się prowadzić w miarę normalne życie. Ważne jest, aby skutki stresu, którego doznają, nie odreagowywali przy chorym lub innych członkach rodziny. Zalecana jest ścisła współpraca z lekarzem lub innymi pracownikami ochrony zdrowia. 
Kończąc, wydaje się, że warto zwrócić uwagę na pewien problem, który w zasadzie z reguły zgłaszany jest lekarzom, bo w istocie ich dotyczy najbardziej. Mowa tutaj o możliwości popełnienia błędu podczas komunikacji z chorym. Ponieważ z reguły błąd ten pochodzi od lekarza, więc często nazywa się go jatrogennym. Każdy ma prawo popełniać błędy, lecz w przypadku chorych, a chorych śmiertelnie w szczególności, ważne są następstwa tych błędów, które mogą być bardzo przykre dla chorego.

Błąd jatrogenny w rozumieniu potocznym jest traktowany jako niezawiniony. Pojawia się on albo w wyniku niedostatecznej wiedzy o funkcjonowaniu psychiki człowieka, albo w następstwie zaniedbania, zapomnienia, pobłażliwości, roztargnienia, przyjęcia egocentrycznej postawy, przyjęcia wzorów środowiska pracy itp.

Podczas prowadzenia badań na każdym etapie istnieje ryzyko popełnienia wyżej wymienionego błędu. Skutki popełnianych błędów mogą należeć do dość błahych, jak np. podwyższenie niepokoju, lub groźnych, jak choćby znaczne pogorszenie stanu somatycznego, lub wręcz wystąpienie innej groźnej dla zdrowia lub życia choroby. Najczęściej jako następstwo wymienia się pogorszenie choroby podstawowej, wystąpienie lub zaostrzenie zaburzeń psychosomatycznych lub rekcji nerwicowych. J a ro s z (1983) wspomina także o możliwym wystąpieniu psychoz reaktywnych.

\section{BIBLIOGRAFIA}

B e d n a r e k Ewa (2002), Zawód zaufania publicznego. Między profesjonalizmem a fuszerka, „Gazeta Prawna", nr 89, s. 24.

B e r s c he i d Ellen, B a r o n Robert, D e r m e r Marshall, L i b m a n Mark (1973), Anticipating Informed Consent: An Empirical Approach, „American Psychologist”, Vol. 28, s. 913-925.

B ę d k o w s k a-K or p a ł a Barbara, G i e r o w s k i Józef Krzysztof (2007), Psychologia lekarska a profesjonalny kontakt lekarza z pacjentem, [w:] Psychologia lekarska w leczeniu chorych somatycznie, B. Będkowska-Korpała, K. J. Gierowski (red.), Wydawnictwo Uniwersytetu Jagiellońskiego, Kraków, s. 7-15.

B o b r o w s k a-N o w a k Wanda (1973), Początki polskiej psychologii, Wydawnictwo PAN, Warszawa.

B or a ty ńska Maria, Konieczniak Przemysław (2001), Prawa pacjenta, Wydawnictwo Difin, Warszawa 2001.

B o r y s Bogusław (2006), Wzrost znaczenia psychologii we współczesnej medycynie; istotne przyczyny, [w:] Psychologia w medycynie (wybrane zagadnienia), B. Borys, M. Mankowicz (red.), Akademia Medyczna w Gdańsku, Gdańsk.

B r z e z i ńs k a Anna (2000), Dziecko w badaniach psychologicznych, [w:] Etyczne dylematy psychologii, J. Brzeziński, M. Toeplitz-Winiewska (red.), Wydawnictwo Fundacji Humaniora, Poznań, s. 221-254.

B r z e z iń s k a Anna, B r z e z i ńs k i Jerzy, E 1 i a s z Andrzej (red.) (2000), Standardy kształcenia psychologów, Wydawnictwo Naukowe Uniwersytetu A. Mickiewicza w Poznaniu, Poznań. 
B r z e z i ń s k i Jerzy (2000), Problemy etyczne badań naukowych i diagnostycznych, [w:] Psychologia. Podręcznik akademicki. Podstawy psychologii, t. 1, J. Strelau (red.), Gdańskie Wydawnictwo Psychologiczne, Gdańsk, s. 523-537.

Brzeziński Jerzy, Toep litz-Winie ws ka Małgorzata (red.) (2000), Etyczne dylematy psychologii, Wydawnictwo Fundacji Humaniora, Poznań.

C hry s to w s k a-J a b ł oń s k a Bogumiła (2006), Mosty czy przepaście w komunikacji lekarz pacjent, „Biuletyn Onkologiczny”, z. 6, s. 77-79.

C h r y s to w s k a-J a bło ń s k a Bogumiła (2006), Psychologiczne aspekty metod leczenia onkologicznego, „Biuletyn Onkologiczny”, z. 6, s. 80-83.

C i s z e w s k i Jerzy (2003), Wybrane instytucje prawa cywilnego, Arche, Gdańsk.

$\mathrm{C}$ z a b a ł a Czesław Jan, S ę k Helena (2005), Wprowadzenie do psychologii klinicznej, [w:] Psychologia. Podręcznik akademicki. Jednostka w spoteczeństwie i elementy psychologii stosowanej, t. 3, J. Strelau (red.), Gdańskie Wydawnictwo Psychologiczne, Gdańsk, s. 555-565.

H e s z e n-N i e j o d e k Irena (2005), Psychologiczne problemy chorych somatycznie, [w:] Psychologia. Podręcznik akademicki. Jednostka w spoleczeństwie i elementy psychologii stosowanej, t. 3, J. Strelau (red.), Gdańskie Wydawnictwo Psychologiczne, Gdańsk, s. 513-531.

H u n t William (1946), The Future of Diagnostics Testing in Clinical Psychology, „Journal of Clinical Psychology", z. 4, s. 311-317.

J a c y s z y n Jerzy (2004), Wykonywanie wolnych zawodów w Polsce, Lexis Nexis, Warszawa.

J a k u b o w s k a-W in i e c k a Anna, W ł o d a r c z y k Dorota (red.) (2007), Psychologia w praktyce medycznej, PZWL, Warszawa.

J a r o s z Marek (1983), Psychologia lekarska, PZWL, Warszawa.

J e d 1 i ń s k i Krzysztof (1992), Jak rozmawiać z tymi co stracili nadzieję, INTRA, Warszawa.

K a p 1 u n Annette (1997), Promocja zdrowia w chorobach przewlektych. Odkrywanie nowej jakości zdrowia, Instytut Medycyny Pracy, Łódź.

Kodeks Etyczno-Zawodowy Psychologa, zatwierdzony przez Walne Zgromadzenie Delegatów Polskiego Towarzystwa Psychologicznego w 1991 roku (1991), Polskie Towarzystwo Psychologiczne, Warszawa.

Konstytucja Rzeczypospolitej Polskiej z dnia 2 kwietnia 1997 r. uchwalona przez Zgromadzenie Narodowe w dniu 2 kwietnia 1997 r., przyjęta przez Naród w referendum konstytucyjnym $w$ dniu 25 maja 1997 r., podpisana przez Prezydenta Rzeczypospolitej Polskiej w dniu 16 lipca 1997 r. (1997), DzU, nr 78, poz. 483.

K ü b l e r-R o s s Elisabeth (1979), Rozmowy o śmierci i umieraniu, PAX, Warszawa.

L i s z e w s k a Agnieszka (1997), Zgoda pacjenta na zabieg leczniczy, „Państwo i Prawo”, vol. 61, nr 1, s. 7-12.

M ą c zk a Grzegorz (2007), Człowiek umierajacy - psychologiczne aspekty opieki paliatywnej, [w:] Psychologia lekarska w leczeniu chorych somatycznie, B. Bętkowska-Korpała, K. J. Gierowski (red.), Wydawnictwo Uniwersytetu Jagiellońskiego, Kraków, s. 241-252.

Nie mczyński Adam (2002), Psycholog - zawodem zaufania publicznego?, Konferencja: „Zawody zaufania publicznego a interes publiczny - korporacyjna reglamentacja versus wolne wykonywanie zawodu", 8.04.2002 r., Komisja Polityki Społecznej i Zdrowia Senatu RP, MPiPS, materiały.

Obwieszczenie Marszałka Sejmu Rzeczypospolitej Polskiej z dnia 2 listopada 2005 r.w sprawie ogłoszenia jednolitego tekstu ustawy o zawodach lekarza i lekarza dentysty (2005), DzU, nr 226, poz. 1943, z późn. zm.

O r o ń s k a Anna (2000), Rozmowa z nieuleczalnie chorym, [w:] Komunikowanie się z pacjentem, J. Barański, E. Waszyński, A. Steciwo (red.), Wydawnictwo Astrum, Wrocław, s. 130-138.

P a l u c h o w s k i Władysław Jacek (2007), Diagnoza psychologiczna, Wydawnictwo Akademickie i Profesjonalne, Warszawa. 
P a 1 u c h o w s k i Władysław Jacek, H o r n o w s k a Elżbieta (2000), Problemy teoretyczne diagnozy psychologicznej, [w:] Psychologia. Podręcznik akademicki. Podstawy psychologii, t. 1, J. Strelau (red.), Gdańskie Wydawnictwo Psychologiczne, Gdańsk, s. 509-521.

P i e t e r Józef (1972), Historia psychologii, PWN, Warszawa.

P o n c z e k Dorota (2000), Prawa pacjenta w Polsce, Wydawnictwo ADI, Łódź.

R e y k ow sk i Janusz (1999), O zmieniajacej się roli psychologii w zmieniajacym się świecie, „Czasopismo Psychologiczne”, vol. 5, nr 3, s. 201.

S a d o c k Benjamin, S a d o c k Virginia (2003), End-of-life Care and Palliative Medicine, „Synopsis of Psychiatry", Vol. 56, s. 1338-1351.

S ę k Helena (2005), Psychologia kliniczna, Wydawnictwo Naukowe PWN, Warszawa.

S k ł o d o w s k i Henryk, R y t y c h Sławomir (2006), Dzieje psychologii łódzkiej w latach 19182005, PTP, Łódź.

S kłod ow sk i Henryk (red.) (1996), Medycyna psychosomatyczna i psychologia chorego somatycznie wobec zagrożenia $i$ wyzwań cywilizacyjnych współczesnego świata, Wydawnictwo Uniwersytetu Łódzkiego, Łódź.

Stachowski Ryszard (2000), Historia psychologii od Wundta do czasów najnowszych, [w:] Psychologia. Podręcznik akademicki. Podstawy psychologii, t. 1, J. Strelau (red.), Gdańskie Wydawnictwo Psychologiczne, Gdańsk, s. 25-66.

Statut Polskiego Towarzystwa Psychologicznego uchwalony przez Walne Zgromadzenie Delegatów PTP dnia 21.09.2005 r. (2007), PTP, Warszawa, (zmieniony 27 stycznia 2007 r., Sąd Rejonowy dla Warszawy, KRS 38 316).

S te c i w k o Andrzej (2000), Zasady komunikowania się lekarza z pacjentem z uwzględnieniem przewlekle i ciężko chorego, [w:] Komunikowanie się z pacjentem, J. Barański, E. Waszyński, A. Steciwo (red.), Wydawnictwo Astrum, Wrocław, s. 121-129.

S te p u la k Marian Zdzisław (2000), Tajemnica zawodowa w działalności badawczej i praktycznej psychologów, [w:] Etyczne dylematy psychologii, J. Brzeziński, M. Toeplitz-Winiewska (red.), Wydawnictwo Fundacji Humaniora, Poznań, s. 123-134.

S z a w a r s k i Zbigniew (2005), Mądrość i sztuka leczenia, Wydawnictwo słowo/obraz terytoria, Gdańsk.

Talarowska Monika, Florkowski Antoni, Orzechowska Agata, Zboralski Krzysztof (2008), Etyka w zawodzie psychologa, „Valetudinaria”, vol. 13, nr 1, s. 7-10.

Ustawa z dnia 5 grudnia 1996 r. o zawodzie lekarza (1997), DzU, nr 28, poz. 152, z późn. zm.

Ustawa z dnia 19 sierpnia 1994 r. o ochronie zdrowia psychicznego (1994), DzU, nr 111, poz. 535, z późn. zm.

Ustawa z dnia 8 czerwca 2001 r. o zawodzie psychologa i samorządzie zawodowym psychologów (2001), DzU, nr 73, poz. 763, z późn. zm.

W a 1 d e n-G a ł u s z k o Krystyna de (2000), U kresu. Opieka paliatywna, czyli jak pomóc choremu, rodzinie i personelowi medycznemu środkami psychologicznymi, Wydawnictwo Medyczne MAKmed, Gdańsk.

Wr z e ś n i e w s k i Kazimierz (2005), Medycyna psychosomatyczna i behawioralna, [w:] Psychologia. Podręcznik akademicki. Jednostka w społeczeństwie i elementy psychologii stosowanej, t. 3, J. Strelau (red.), Gdańskie Wydawnictwo Psychologiczne, Gdańsk, s. 450-456.

Zboralski Krzysztof, Florkowski Antoni, Talarowska-Bogusz Monika, Mac a n d e r Marian, G a $\nmid$ e c k i Piotr (2008), Quality of Life and Emotional Functioning in Selected Psychosomatic Diseases, „Postępy Higieny i Medycyny Doświadczalnej”, nr 62, s. 1-6.

Z i m b a rd o Philip G., R u ch Floyd L. (1994), Psychologia $i$ życie, Wydawnictwo Naukowe PWN, Warszawa. 


\section{Agata Orzechowska, Monika Talarowska, Krzysztof Zboralski}

\section{SELECTED PROBLEMS AND ETHICAL DILEMMAS IN PSYCHOLOGICAL ASPECTS OF SCIENTIFIC RESEARCH AND CLINICAL}

Clinical psychology as a profession and as a scientific discipline is one of those areas of human activity in which the center of attention and interaction is a man. Interpersonal relationships established by a psychologist acting both as practice and as a researcher and teacher, always have an ethical dimension. These relationships, however, have specific, asymmetric nature of the advantage resulting from interpersonal competence on the side of a psychologist who has specialized knowledge and techniques to the learning of other people and the impact on them. Due to the conduct of research and clinical trials of another person as an object of research, the psychologist must deal with ethical issues, which do not relate to other scientific fields.

Keywords: psychologist, research, clinical diagnosis, ethics. 